\title{
Monostearin effects on the formation of precipitate in palm oil biodiesel and petroleum diesel blends with various storage temperature
}

\author{
Mohamad Aufar Ghaizani, Imam Abdurrosyid, Imam Paryanto, and Misri Gozan* \\ Department of Chemical Engineering, Faculty of Engineering, Universitas Indonesia, Depok 16424, \\ Indonesia
}

\begin{abstract}
Biodiesel is one of the renewable energy forms that is on demand in Indonesia. In the biodiesel production process, impurities such as Saturated Monoglycerides (SMG) in the form of monostearin that precipitate at low temperature are commonly formed. This is caused by high Final Melting Temperature (FMT) of SMG. Formation of solid deposits when it reaches a temperature above Cloud Point $(\mathrm{CP})$ is then unavoidable under these conditions. The use of palm oil biodiesel and petroleum diesel blends (BXX) with biodiesel blend ratio of 10\% (B10), 20\% (B20) and 30\% (B30) accelerates precipation process which renders clogging on fuel filters. These works examined the effect monostearin content and temperature on the precipitation rate. Investigation is carried out at $15^{\circ} \mathrm{C}, 20^{\circ} \mathrm{C}, 25^{\circ} \mathrm{C}$, and room temperature $\left(30-33^{\circ} \mathrm{C}\right)$ with varying content of monostearin $(0.4 \%, 0.7 \%$, and $0.9 \%$ ). Early results show that for $0.4 \%$ monostearin content in $100 \mathrm{ml}$ B20, the amount of precipitate formed at temperature $15 \mathrm{oC}$ was $31.3 \mathrm{mg}$. This value was higher than that at room temperature $(6.3 \mathrm{mg})$ after 2 weeks storage time. This value was higher compared to B20 $(21.5 \mathrm{mg})$. This indicates that as the biodiesel ratio in BXX become higher, the amount of FAME will increase which effect monostearin solubility in BXX at low temperature.
\end{abstract}

\section{Introduction}

The energy crisis is the biggest problem we faced today, where the energy crisis will bring a great impact on the community. Demand and needs of the energy alone are increasing each day while energy resources declining and soon it will run out. This suggests that renewable energy should be of more concern because even though fossil fuels still be the primary option for energy in the world but eventually increase $\mathrm{CO} 2$ levels and cause greenhouse effects. To maintain environmental and the sustainability of energy resources, alternatives of fuel source is needed.

Biodiesel is a liquid-form fuel produced from biomass from various fields of agriculture, forest products, and biodegradable factory waste [3]. Biodiesel consists of long chains of methyl or ethyl esters generally produced by transesterification of short chain monohydric alcohols. In

\footnotetext{
* Corresponding Author; misrigozan@gmail.com
} 
biodiesel production process formed impurities such as saturated monoglycerides (SMG) and precipitate at low temperature operating conditions. This is due to high final melting temperature (FMT) or melting point of SMG and will form solid deposits above cloud point (CP). The use of biodiesel mixed with petroleum diesel will enhance precipitation at low temperatures and will cause clogging of fuel filters in a vehicle [4].

Bondioli et al (2008) examined the occurence of precipitation in FAME production of palm oil and soybean oil from the final abstertion and formed insoluble white solids. Tang et al (2008) examined solid residue content from SME (soybean methyl ester), FAME-cotton seed, and animal fat FAME and mixed with USLD 2 using GC and FT-IR. The results of FT-IR and GC analysis shows that precipitate on SME biodiesel mostly contain Free Steryl Glucoside (FStG). In addion, the precipitates formed in animal fat biodiesel mostly contain saturated monoglycerides in the form of monopalmitin and monostearin while in cotton seed biodiesel the precipitate mostly contain FStG and saturated monoglycerides.

The soluble precipitate will again become impurities [2]. Impurities, either derived from raw materials or from other components resulted in biodiesel production, in small concentrations, may affect the performance of biodiesel at low temperatures. In the biodiesel production process often found residue produced by imperfect biodiesel conversion and appears in the final product of biodiesel. Insoluble impurities in biodiesel become important parameter because it will cause clogging in fuel filter in a vehicle [4].

Currently there are addiotional parameters on ASTM in the form of Cold Soaking Filtration Test (CSFT) and Filter Blocking Test (FBT) which will become mandatory for biodiesel that will be blend with petroleum diesel. FBT is a dimensionless unit that defines filter blocking or plugging tendency of particulate, taken from the volume needed to achieve pressure difference of $105 \mathrm{kPa}$ or $300 \mathrm{ml}$ of volume at a velocity of $20 \mathrm{ml} / \mathrm{min}$. CSFT combine cooling temperature and time which in this case $4^{\circ} \mathrm{C}$ and 16 hours for ASTM (cold soaking).

\section{Materials and Methods}

\subsection{Fuels and Monostearin}

Biodiesel used in this study was bought from palm oil biodiesel from Wilmar Nabati Indonesia CO., meanwhile the petroleum diesel from Shell Indonesia that has aromatic content $2.54 \%$. These biodiesel and petroleum diesel were characterized by using Gas Chromatography/Mass Spectrometry as shown in the Table 1.

Table 1. Biodiesel and Petroleum Diesel Characterization

\begin{tabular}{|l|l|l|l|}
\hline \multicolumn{1}{|c|}{ Parameter } & Units & WNI & Shell \\
\hline Density at $15^{\circ} \mathrm{C}$ & $\mathrm{kg} / \mathrm{m}^{3}$ & 856.8 & 842.5 \\
\hline Cloud Point & ${ }^{\circ} \mathrm{C}$ & n.a & 1.7 \\
\hline FAME Content & $\%$ & 99.5 & n.a \\
\hline Oxidation Stability & minute & 601.5 & n.a \\
\hline Aromatic Content & $\%$ & n.a & 2.54 \\
\hline Monoglycerides Content & $\% \mathrm{vol}$ & 0.4 & n.a \\
\hline Total Glycerol & $\% \mathrm{vol}$ & 0.1 & n.a \\
\hline Free Glycerol & $\%$ vol & 0.003 & n.a \\
\hline
\end{tabular}

The monostearin is known to have high influence in the precipitate formation [4]. Monostearin used in this study were produced by TCI with $63.4 \%$ purity. Monostearin were added to this TCI-biodiesel, so the total volumetric content of monostearin became $0.4 \%$, 
$0.71 \%$, and $0.92 \%(\mathrm{v} / \mathrm{v})$. Ratio of blending in biodiesel and petroleum diesel also varied and characterized with methods listed in the Table 2.

Table 2. Characterization of BXX WNI-S

\begin{tabular}{|c|c|c|c|c|c|c|c|}
\hline \multirow[t]{2}{*}{ Parameters } & \multirow[t]{2}{*}{ Units } & \multicolumn{3}{|c|}{ Results } & \multicolumn{2}{|c|}{$\begin{array}{l}\text { Standard } \\
\text { Solar } 48\end{array}$} & \multirow[t]{2}{*}{ Methods } \\
\hline & & B10 & B20 & B30 & Min & Max & \\
\hline Density at $15^{\circ} \mathrm{C}$ & $\mathrm{kg} / \mathrm{m}^{3}$ & 848.7 & 841.1 & 849.1 & 815 & 870 & ASTM D4052 \\
\hline Cloud Point & ${ }^{\circ} \mathrm{C}$ & 3.4 & 4.3 & 4.7 & - & 18 & ASTM D5773 \\
\hline Sediment & $\%$ mass & 0 & 0 & 0 & - & 0.6 & ASTM D473 \\
\hline FAME Content & $\% \mathrm{vol}$ & 10.1 & 19.9 & 29.9 & - & 20 & ASTM D664 \\
\hline $\begin{array}{l}\text { Oxidation Stability } \\
\text { Rancimat Methods }\end{array}$ & Hour & 44.22 & 36.87 & 36.59 & 35 & - & EN 15751 \\
\hline
\end{tabular}

The results of characterization of biodiesel-petroleum diesel blends for blending ratio B10, B20, and B30 without monostearin content modification in Table 2 shows that all cloud points are below the lowest temperature used in this study $\left(15^{\circ} \mathrm{C}\right)$ with the highest value came from $\mathrm{B} 30$ blend, that is $4.7^{\circ} \mathrm{C}$. This indicated that all the blends were qualified to be used to quantify the formation of precipitate above the cloud points.

\subsection{Beaker Test}

In ASTM D7501 (Standard Test Method for Determination of Fuel Filter Blocking Potential of Biodiesel (B100) Blend Stock by Cold Soak Filtration Test (CSFT)), $300 \mathrm{ml}$ of biodiesel (B100) stored at temperature $4.5 \pm 0.5^{\circ} \mathrm{C}$ for 16 hours, warmed up to $25 \pm 1{ }^{\circ} \mathrm{C}$ (standard room temperature), then filtered with vacuum filter through $0.7 \mu \mathrm{m}$ fiber glass filter on $70-85 \mathrm{kPa}$ vacuum level. ASTM D7501 method is inefficient when used for large samples and it doesn't show the effect of different storage temperature to the formation of a precipitate. In this study, the temperature and soaking time were modified. $100 \mathrm{ml}$ of BXX (Biodiesel and Petroleum Diesel Blend) stored in cooling chamber with a temperature of $15^{\circ} \mathrm{C}, 20^{\circ} \mathrm{C}, 25^{\circ} \mathrm{C}$, and room temperature (range from $30^{\circ} \mathrm{C}$ to $33^{\circ} \mathrm{C}$ ) for 2 weeks. These variation is based on real operational condition and storage of fuel in lower temperature area.

\section{Results}

Increasing in blending ratio will results in cloud point rise. The cloud point of palm oil biodiesel is higher than petroleum diesel. This study used variation of blending ratio, that was B10, B20, and B30. The results are shows in Table 3.

Table 3. Precipitation Formed from Beaker Test $(\mathrm{mg} / \mathrm{ml})$

\begin{tabular}{|c|c|c|c|c|}
\hline \multirow{2}{*}{ BXX - Monostearin Content } & \multicolumn{4}{|c|}{ Temperature } \\
\cline { 2 - 5 } & $\mathbf{1 5}$ & $\mathbf{2 0}$ & $\mathbf{2 5}$ & Room Temperature \\
\hline B10 - 0.4\% & 0.192 & 0.141 & 0.100 & 0.070 \\
\hline B10 - 0.71\% & 0.372 & 0.238 & 0.111 & 0.109 \\
\hline B10 - 0.94\% & 0.540 & 0.445 & 0.277 & 0.279 \\
\hline B20 - 0.4\% & 0.313 & 0.215 & 0.182 & 0.063 \\
\hline B20 - $0.71 \%$ & 0.853 & 0.481 & 0.226 & 0.254 \\
\hline
\end{tabular}




\begin{tabular}{|c|c|c|c|c|}
\hline B20 - 0.94\% & 1.302 & 1.109 & 0.726 & 0.627 \\
\hline B30 - 0.4\% & 0.358 & 0.282 & 0.185 & 0.127 \\
\hline B30 - 0.71\% & 0.853 & 0.481 & 0.226 & 0.254 \\
\hline B30- $0.94 \%$ & 2.187 & 1.711 & 1.096 & 1.049 \\
\hline
\end{tabular}

The results in Table 3 show that the effect of blending ratio at temperature $15^{\circ} \mathrm{C}, 20^{\circ} \mathrm{C}$, and $25^{\circ} \mathrm{C}$ were significant compared to the effect of blending ratio at room temperature $\left( \pm 30^{\circ} \mathrm{C}\right)$. Precipitate formed in $\mathrm{B} 20$ was significantly lower at $15^{\circ} \mathrm{C}$. The difference on the formation of precipitate in $\mathrm{B} 20$ and $\mathrm{B} 30$ was not significant above temperature $15^{\circ} \mathrm{C}$. The results also showed that precipitate was more likely to form as the percentage of monostearin increase. In B10, the effect of temperature on the precipitate formation was not significant. The temperature affected precipitation more on biodiesel with higher blending ratio.

a

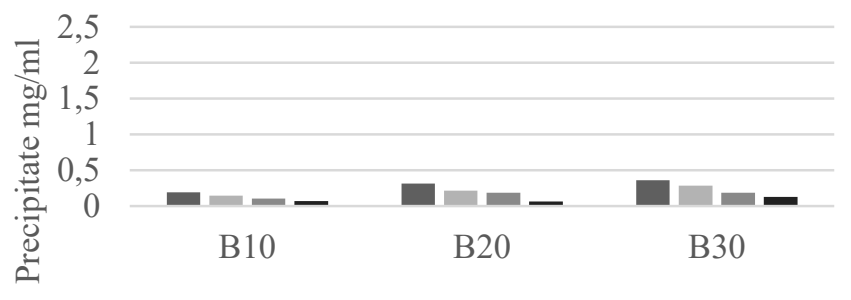

Temperature $\left({ }^{\circ} \mathrm{C}\right) \quad \square 15 \quad \square 20 \quad \square 25 \quad \square$ Room

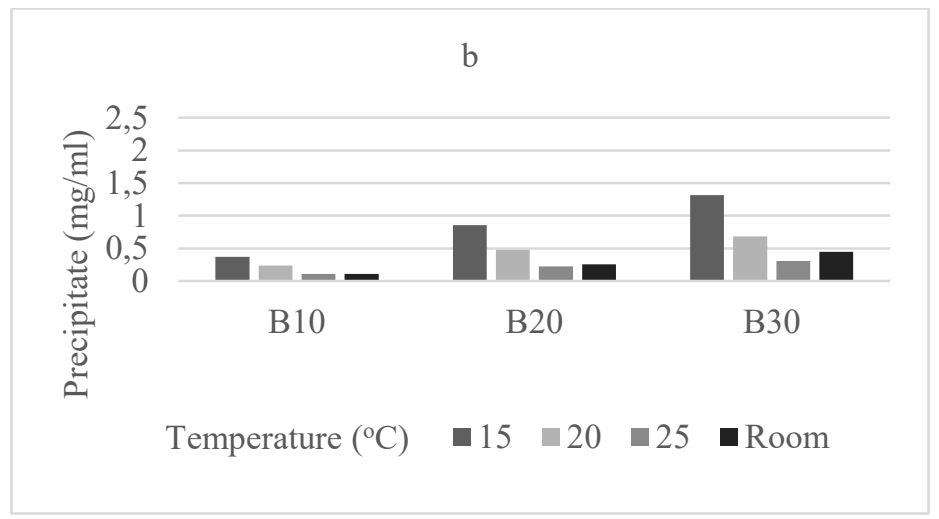




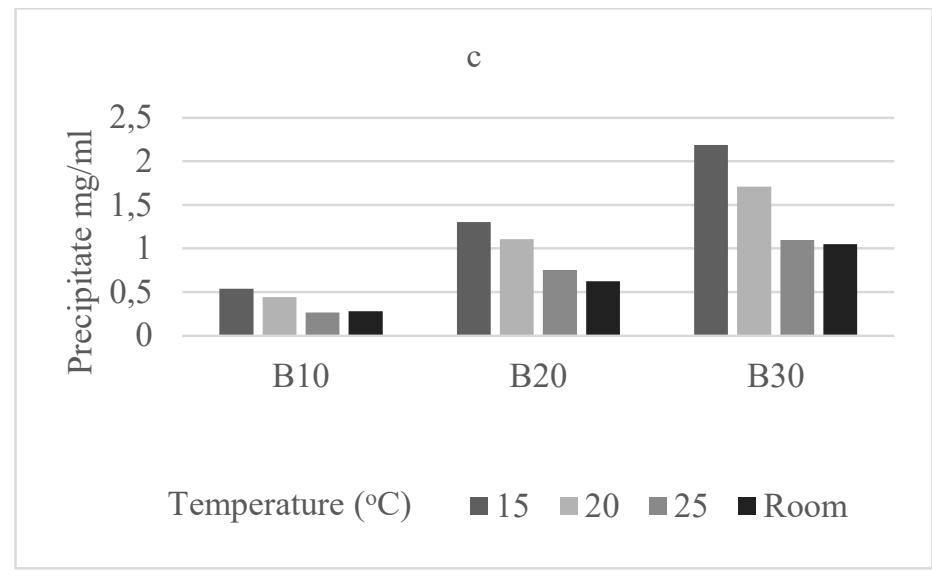

Fig. 1. Comparison of precipitate formed in BXX (Biodiesel and Petroleum Diesel Blend) resulted from beaker test with (a) $0.4 \%$ Monostearin Content, (b) $0.71 \%$ Monostearin Content, and (c) $0.92 \%$ Monostearin Content

JAMA (Japan Automobiles Manufacturers Association) conducted soaking test on B20 with high and low monostearin content on various temperature $\left(5^{\circ} \mathrm{C}, 15^{\circ} \mathrm{C}, 20^{\circ} \mathrm{C}\right.$, and $\left.25^{\circ} \mathrm{C}\right)$. The result shows that the precipitation in low monostearin content was not found at all temperatures. Meanwhile, in high monostearin content the precipitate was formed at temperature $5^{\circ} \mathrm{C}, 15^{\circ} \mathrm{C}$, and $20^{\circ} \mathrm{C}$ only (GAIKINDO, 2015). Those results corresponding with this study where on cold soaking at temperature above $20^{\circ} \mathrm{C}$ and blending ratio below $\mathrm{B} 20$ did not affect precipitate formation significantly.

\section{Conclusion}

This study has shown that monostearin contents and temperature affected the formation of precipitate on biodiesel-petroleum diesel blends after 2 weeks storage period time. The lower temperature and higher monostearin content produced more precipitate. The higher percentage of B100 in blending ratio also promotes the formation of precipitate.

\section{Acknowledgments}

Authors are grateful for the financial support provided by Hibah Publikasi Internasional Terindeks untuk Tugas Akhir Mahasiswa (PITTA) through Universitas Indonesia and research facilities provided by Univesitas Indonesia (2477/UN2.R3.1/HKP.05.00/2018).

\section{References}

1. P. Bondioli, N. Cortesi and C. Mariani, Identification and quantification of steryl glucosides in biodiesel, European Journal of Lipid Science and Technology 110(2):120-6, (2008)

2. G. Chupka, L. Fouts, J. Lennon, T. Alleman, D. Daniels, R. Mccormick, Saturated monoglyceride effects on low-temperature performance of biodiesel blends. Fuel Processing Technology; 118:302-9, (2014)

3. A. Dufey, Biofuels Production, Trade, and Sustainable Development: Emerging Issues. London, (International Institute for Environment and Development, 2006) 
4. RO. Dunn, Effects of minor constituents on cold flow properties and performance of biodiesel. Progress in Energy and Combustion Science;35(6):481-9. (2009)

5. GAIKINDO. Bio Diesel B20 Movement (Technical Concern). (2015)

6. H. Tang, S. Salley, K. Simonng, Fuel properties and precipitate formation at low temperature in soy-, cottonseed-, and poultry fat-based biodiesel blends. Fuel 87(1314):3006-17, (2008) 